\title{
Populist Challenges to Constitutional Interpretation in Europe and Beyond
}

Edited by Fruzsina Gárdos-Orosz and Zoltán Szente

First published 2021

ISBN: 978-0-367-71009-5 (hbk)

ISBN: 978-0-367-71013-2 (pbk)

ISBN: 978-1-003-14894-4 (ebk)

\section{Chapter 1}

Populism and populist constitutionalism

Zoltán Szente

CC BY-NC-ND 4.0

DOI: $10.4324 / 9781003148944-2$

Centre for Social Sciences Hungarian Academy of Sciences Centre of Excellence 


\title{
1 Populism and populist constitutionalism
}

\author{
Zoltán Szente
}

\subsection{Introduction}

In order to get closer to answering the questions set out in the Introduction, i.e. to understand the relationship between populism and constitutional interpretation, it is necessary to provide the framework of the academic discourse and the major attempts to conceptualize the two key concepts of this book. Populist constitutionalism is a kind of intermediate category between these two concepts and refers to the constitutional approach, aspirations, or activities of populism. Having regard to the great variety of relevant definitions, this study has no ambition to develop authentic conceptualizations - our goal is simply to bring the reader closer to the academic discourse on populism, populist constitutionalism, and constitutional interpretation, and to provide help for a better understanding of the studies collected in this volume. In doing so, we use the classical conceptualization technique which determines the subject of the research by identifying its most important conceptual criteria.

Among the sources of these criteria, we can find both normative theories and descriptive works; in fact, this chapter aims to provide a comprehensive literature review of these categories.

\subsection{The impalpable concept of populism}

The conceptualization of populism is difficult not only because it is a very abstract concept, but also because it signifies a phenomenon that does not fit, or fits only with difficulty, into other existing conceptual frameworks. This means that the various manifestations of populism cannot be placed in the traditional dichotomies of the political right and left, democracy and autocracy, and cannot be attributed to specific time periods or geographical regions. There is not even a consensus as to whether this concept actually refers to a particular political organization, ideology, political aspiration, or style. Therefore, as a specific political phenomenon, it is often compared to a chameleon that adapts to the colour of its environment. ${ }^{1}$ 
Some claim that almost every scholar has an individual definition of populism that suits his or her own interests. ${ }^{2}$ Indeed, the conceptualization of populism has a specific, ever-expanding literature, but no consensual concept has emerged as a result. This may also be due to the fact that populism does not have an exemplar, a universally accepted ideal-type that exists in reality, and, by the same token, different conceptualizations are attempted in the discourse on the topic. It is common to highlight only one defining criterion, but many seek to identify populist policies or movements on the basis of several criteria, ${ }^{3}$ and there are even examples which define primary and secondary aspects (on the basis of which different types of populism can also be distinguished). ${ }^{4}$ Some definitions of populism are normative, classifying certain political phenomena as populist according to whether they meet a pre-established general conceptualization, while others approach the notion of populism on an empirical basis by generalizing the main characteristics of certain political systems or movements. As a consequence, "[a] persistent feature of the literature on populism is its reluctance - or difficulty - in giving the concept any precise meaning', and any '[n]otional clarity - let alone definition - is conspicuously absent'. ${ }^{5}$

Therefore, some suggest that populism should be given a 'minimalist' definition that includes as many of the cases discussed as possible in its own conceptual scope ${ }^{6}$ although an overly broad definition would call into question the use of this category for scientific analysis.

Due to this conceptual diversity and indeterminacy, it is not surprising that there are also authors who think that the concept of populism as such is less suitable for exploration by the social sciences. ${ }^{7}$

However, the use of the term is extremely widespread in political science and even in constitutional scholarship, and, in addition, despite different attempts at conceptualization, this phenomenon has several features on which there is a broad consensus among scholars. Therefore, it is still worth taking a closer look at the best-known definitions of populism and the criteria most often attributed to populists.

2 Jürgen Mackert, 'Introduction. Is There Such a Thing as Populism?' in Gregor Fitzi, Jürgen Mackert, and Bryan S. Turner (eds.), Populism and the Crisis of Democracy. Volume 1: Concepts and Theory (Routledge 2018) 2.

3 Yves Mény and Yves Surel, 'The Constitutive Ambiguity of Populism' in Yves Mény and Yves Surel (eds.), Democracies and the Populist Challenge (Palgrave MacMillan 2002) 1-21.

4 For the latter, see for example Paul Taggart, 'Populism and "Unpolitics"' in Gregor Fitzi, Jürgen Mackert, and Bryan S. Turner (eds.), Populism and the Crisis of Democracy. Volume 1: Concepts and Theory (Routledge 2018) 80.

5 Ernesto Laclau, On Populist Reason (Verso 2005) 3.

6 Cristóbal Rovira Kaltwasser, 'How to Define Populism? Reflections on a Contested Concept and its (Mis)use in the Social Sciences' in Gregor Fitzi, Jürgen Mackert, and Bryan S. Turner (eds.), Populism and the Crisis of Democracy. Volume 1: Concepts and Theory (Routledge 2018) 64.

7 Cathérine Colliot-Thélène, 'Populism as a Conceptual Problem' in Gregor Fitzi, Jürgen Mackert, and Bryan S. Turner (eds.), Populism and the Crisis of Democracy. Volume 1: Concepts and Theory (Routledge 2018) 19. 


\subsection{Conceptualizing populism}

\subsubsection{Historical background}

Populism is not a recently discovered concept; its roots go back to the 19th century, and it was first used, perhaps, for the Populist Party in the United States and for the Narodnik movement in Russia at the end of that century. In reality, however, its use became widespread in post-World War II Europe, when it began to be applied to various political organizations, such as the French Poujade movement, the right-wing Development Party of the Danish Mogens Glistrup, and the left-wing movements that emerged in the 1970s and 1980s, such as the green parties in Western Europe. ${ }^{8}$ These movements had different ideologies and political aspirations, but their common features were radicalism and opposition to the ruling political establishment.

Subsequently, populism emerged in various waves and was most often linked in the 1990s and 2000s to radical right-wing parties such as the Freedom Party (FPÖ) led by Jörg Haider in Austria, the French National Front by Jean-Marie Le Pen, Forza Italia in Italy which was founded and led by Silvio Berlusconi, or the Pim Fortuyn List (LPF) in the Netherlands. At the same time, some radical leftist movements have also been characterized as populists, such as the German The Left (Die Linke) or, at the same time, the Dutch and Scottish socialist parties. Although mostly outsider parties have been labelled in this way, some claim that 'since the early 1990s populism has become a regular feature of politics in western democracies'.

However, populism also emerged outside Europe in the 20th century, and one of its best-known examples was the movement of Juan Perón in Argentina, which actually created traditions that persist to this day; and several other Latin American regimes have been considered populists since the 1960s. In the USA such a trait has often been assigned to the so-called alternative (i.e. not supported by the two major parties) presidential candidates, such as Ross Perot, Ralph Nader, and Pat Buchanan, but some also consider McCarthyism, which has been developing since the 1940s, to be populist. ${ }^{10}$ Furthermore, populism was not limited to outsider or alternative movements, parties, or politicians, since many observers described such leading politicians as Tony Blair as populists, on the basis of his third-way program, ${ }^{11}$ and this is how US President Jimmy Carter described himself. ${ }^{12}$

The latest surge of populism emerged in the 2010s and has now become so prevalent that it definitely deserves special attention. It is believed that the global economic crisis that erupted in 2008, the refugee crisis that peaked in 2015 , and the terrorist attacks of 2010 s all fuelled increasingly authoritarian

8 Cas Mudde, 'The Populist Zeitgeist' (2004) 39 Government and Opposition 548.

9 Ibid. 551. See also Jack Haward, Elitism, Populism, and European Politics (Oxford University Press 1996) 10.

10 Jan-Werner Müller, What Is Populism? (University of Pennsylvania Press 2016) 91.

11 Mudde (n 8) 551.

12 Müller (n 10) 91. 
populist regimes in several post-communist countries in Central and Eastern Europe, strengthened the anti-immigrant and EU-sceptical populist movements in Western Europe, and played a role in events such as the withdrawal of the United Kingdom from the European Union. In 2014, 24 of the then 28 member states of the EU had populist parties in their parliaments. ${ }^{13}$

In the United States, the appearance, and subsequent development, of the Tea Party since the early 2000 s, a process that reportedly culminated in the election of Donald Trump in 2016, is seen as part of a populist wave. But populism is present in several countries in Latin America (especially in Venezuela, Bolivia, Ecuador, and Brazil) and Asia (in the Philippines).

According to some, the novelty of today's populism is precisely its intensity and prevalence in constitutional democracies. ${ }^{14}$

\subsubsection{The dimensions of populism}

But what connects these vastly different politicians, movements, and political systems?

According to perhaps the most quoted definition, populism is

a thin-centered ideology that considers society to be ultimately separated into two homogeneous and antagonistic camps, 'the pure people' versus the 'corrupt elite', and which argues that politics should be an expression of the volonté générale (general will) of the people. ${ }^{15}$

In this sense, populism only provides a framework that can be filled with substantive ideologies such as socialism or conservatism. ${ }^{16}$ This means that although it can be considered an ideology, it is not a system of ideas that provides a comprehensive explanation for social coexistence or that defines the ideal of the best political system. Its central idea is to represent the 'real' interests of the people, ${ }^{17}$ as opposed to the political elite that holds

13 Sofie Blombäck, 'Populism as a Challenge to Liberal Democracy in Europe' in Antonia Bakardjieva, Engelbrekt Niklas Bremberg, Anna Michalski, and Lars Oxelheim (eds.), The European Union in a Changing World Order. Interdisciplinary European Studies (Palgrave Macmillan 2020) 227-229.

14 Nadia Urbinati, 'Political Theory of Populism' (2018) 22 Annual Review of Political Science 112.

15 Cas Mudde and Rovira Kaltwasser, Populism: A Very Short Introduction (2nd ed. OUP 2017) 5 .

16 Axel Mueller, "The Meaning of 'Populism" (2019) 45 Philosophy and Social Criticism, 1029; Bojan Bugarič, 'The Two Faces of Populism: Between Authoritarian and Democratic Populism' (2019) 20 German Law Journal 392; Théo Fournier, 'From Rhetoric to Action, a Constitutional Analysis of Populism' (2019) 20 German Law Journal 363; Mudde (n 8) 544 .

17 Julian Scholtes, 'The Complacency of Legality: Constitutionalist Vulnerabilities to Populist Constituent Power' (2019) 20 German Law Journal 352. 
(or usurps) power. ${ }^{18}$ In other words, its defining characteristics are popular sovereignty and anti-elitism, which overrides the traditional left-right dichotomy of political ideologies ${ }^{19}$ and is therefore difficult to classify among their traditional forms.

As has been stated by Jan-Werner Müller, who wrote a short monograph on the concept, populism is a specific moral conception of politics that contrasts a morally clean and united people with an elite that is supposed to be corrupt. ${ }^{20}$ This kind of interpretation already leads to a conception of populism that identifies the concept with specific political aspirations. In this framework of conceptualization, the main objective of populism is to protect the ordinary citizens from elites and foreign groups (such as immigrants), and to replace corrupt elites. ${ }^{21}$ It is a political trend that 'is inherently hostile to the idea and institutions of liberal democracy or constitutional democracy' ${ }^{22}$

One of the crucial questions in the conceptualization of populism is its relationship to democracy, which is the most widely discussed topic in the relevant political science academic discourse. In this respect, the range of positions to found in the literature is particularly wide. At one end of the range of opinions are perceptions that view populism as a challenge to liberal democracy (or its elite) which is not in itself anti-democratic, even if its concept differs from that of Western-type constitutional democracy. ${ }^{23}$ According to this view, populism can also be seen as an attempt at a correction of democracy that gives voice to groups that are not represented by elites. ${ }^{24}$ Proponents of this position often cite examples that did not lead to an authoritarian system ${ }^{25}$ but, on the contrary, attempted to make democracy more inclusive. ${ }^{26}$ And although authoritarian populism has indeed taken on the hegemonic form today, many authors believe that democratic populism is also possible. This line has historically included in the United States the presidency of Andrew Jackson and the New Deal policy of Franklin Delano Roosevelt, and today in Europe the populism represented by the Spanish Podemos or the Greek Syriza Party. ${ }^{27}$ Overall, therefore, after coming to

18 Margaret Canovan, 'Trust the People! Populism and the Two Faces of Democracy' (1999) 47 Political Studies 3; Mudde (n 8) 543.

19 Bojan Bugarič and Alenka Kuhelj, 'Varieties of Populism in Europe: Is the Rule of Law in Danger?' (2018) 10 Hague Journal on the Rule of Law 22.

20 Müller (n 10) 39.

21 Roger Eatwell and Matthew Goodwin, National Populism: The Revolt Against Liberal Democracy (Penguin 2018) 55-56.

22 Mudde (n 8) 561.

23 Eatwell and Goodwin (n 21) xi-xii.

24 Cristóbal Rovira Kaltwasser, 'The Ambivalence of Populism: Threat and Corrective for Democracy' (2012) 19 Democratization 185.

25 Paul Blokker, 'Varieties of Populist Constitutionalism: The Transnational Dimension' (2019) 20 German Law Journal 350.

26 Bojan Bugarič, 'Could Populism Be Good for Constitutional Democracy?’ (2019) 15 Annual Review of Law and Social Science 43.

27 Ibid. 43,46 . 
power, despite transforming democratic principles, populism does not break with democracy itself. ${ }^{28}$

However, according to the opposite view, a historical comparison shows that if populists come to power, they will build a system that is democratic but not liberal in that it merely imitates liberal principles and institutions but ultimately undermines liberal democracy. ${ }^{29}$ In fact, this is a more frequent view, which sees populism as an authoritarian challenge to liberal democracy, which does not reject the principle of representation in modern democracies but is not considered democratic precisely because it promotes a conception of representation that claims exclusiveness inasmuch as populists consider themselves as the only legitimate representatives of the people. By this means, they are a real threat to democracy, ${ }^{30}$ and, in the long run, they dismantle constitutional democracy ${ }^{31}$ and do not introduce an open dictatorship simply because this would come at too high a political price. ${ }^{32}$ Kim Lane Scheppele openly views politicians, otherwise characterized as populists, as autocrats who capture state institutions and use constitutional and democratic tools to destroy constitutional democracy. The new autocrats not only exploit popular distrust of public institutions but also attack the principles of liberal and democratic constitutionalism because they want to consolidate their own power and, while maintaining the appearance of democracy and the rule of law, use their democratic authorization to remove the limits on executive power. ${ }^{33}$

However, many authors think that the relationship between populism and democracy cannot be characterized in general terms, because any assessment of this issue largely depends on the normative presuppositions regarding democracy: thus, for example, adherents of liberal democracy generally see populism as a pathological phenomenon, while proponents of radical democracy hold that it strengthens representation; therefore, the evaluation of the relationship is less an empirical but rather a theoretical question, the answer to which depends on speculation as to how democracy should work. ${ }^{34}$

Some scholars simply use the concept of populism to denote political systems, parties, or movements that promote populist principles or follow such an ideology. Populism is accordingly a 'wide contemplative frame', marking very different left- and right-wing political regimes, which have in common

28 Urbinati (n 14) 118.

29 Takis S. Pappas, 'Populists in Power' (2019) 30 Journal of Democracy 70, 72, 82.

30 Müller (n 10) 103.

31 Jan-Werner Müller, 'Populism and Constitutionalism' in Cristóbal Rovira Kaltwasser, Paul Taggart, Paulina Espejo Ochoa, Pierre Ostiguy (eds.), The Oxford Handbook of Populism (Oxford University Press 2017) 603.

32 Müller (n 10) 50.

33 Kim Lane Scheppele, 'Autocratic Legalism' (2018) 85 The University of Chicago Law Review 547.

34 Kaltwasser (n 24) 185. 
that they refer to the unified people as the ultimate source of political morality and public power. ${ }^{35}$

Others see populism only as a specific political style or rhetoric that refers to the power of the people or is based on anti-minority policies and attitudes. ${ }^{36}$

\subsubsection{Types of populism}

The vagueness of the concept of populism is counterbalanced by several authors by distinguishing between its types, often classifying extremely different groups or ideological creeds into this category. As already mentioned, the loose ideological frameworks of populism make it inclusive for traditional political streams, so it is not surprising that many differentiate between leftwing and right-wing populism and populists according to what values are associated with their ideology or ambitions, or from which social group they expect electoral support. ${ }^{37}$ For example, Viktor Orbán and his party, Fidesz in Hungary, the informal leader in Poland, Jarosław Kaczyński and the ruling Law and Justice Party (Prawo i Sprawiedliwość, PiS), or the German opposition party Alternative for Germany (Alternative für Deutschland, AfD), are considered right-wing populists. In contrast, the Greek ruling party, Syriza and the Spanish opposition Podemos, or Bernie Sanders, a Democratic presidential candidate in 2016 and 2020, are generally characterized as leftists. It should also be noted that there are occasionally significant political-ideological cleavages between like-minded populist parties and movements, which makes the picture even less clear. In Europe, for example, some left-wing and right-wing parties support both the euro and European integration, while many other populist parties are Eurosceptic. ${ }^{38}$

Similarly, it is common to distinguish between 'negative' and 'positive', ${ }^{39}$ 'good' and 'bad', 'authoritarian' and 'emancipatory' ${ }^{40}$ populism, groups which are in fact based on the relationship of a particular populist policy regarding democracy, and accordingly the distinction is made between authoritarian and democratic populism. Thus, the populist regimes in Hungary and Poland are often seen as authoritarian based on their nationalism and the semi-authoritarian nature of their legal and political reforms, ${ }^{41}$ as opposed to Western European populism, which has not destroyed liberal

35 Neil Walker, 'Populism and Constitutional Tension' (2019) 17 International Journal of Constitutional Law 517, 519; Fournier (n 16) 363.

36 See on this, Aziz Z. Huq, 'The People Against the Constitution' (2018) 116 Michigan Law Review 1124; and Mueller (n 16) 1130; Fournier (n 16) 365; Blombäck (n 13) 219.

37 Mark Tushnet, 'Comparing Right Wing and Left Wing Populism', in Mark A. Graber, Sanford Levinson and Mark Tushnet (eds.), Constitutional Democracy in Crisis? (Oxford University Press 2018).

38 Bugarič (n 16) 396.

39 See on this, Henrik Bang and David Marsh, 'Populism: A Major Threat to Democracy?' (2018) 39 Policy Studies 3.

40 Bugarič (n 26) 42.

41 For example, Bugarič (n 16) 393, Bugarič and Kuhelj (n 19) 22. 
constitutionalism and the rule of law. ${ }^{42}$ In particular, there are those who emphasize the democratic features of populism, arguing that populism provides responses to the real problems of liberal democracies, such as the gap between the representative institutions and the represented people ${ }^{43}$ or the 'lack of possibilities for meaningful civic engagement' in public decision-making. ${ }^{44}$

One of the best-known scholars of populism, Margaret Canovan, says there can be different varieties of populism depending on against what type of establishment they mobilize, because her approach is to define someone as populist because of how he or she relates to the power structure. ${ }^{45}$ Other views suggest that while the original notion of populism, based on the juxtaposition of mass and elite, is often associated with authoritarianism and xenophobia, the latter phenomena should not necessarily be classified as populism because this kind of conceptualization is not useful for the analysis. ${ }^{46}$

\subsection{The mysterious notion of populist constitutionalism}

The debates on populism have also reached the constitutional discourse, recognizing that one of the distinguishing features of modern populism is its 'constitutional project', that is, the ambitions of populists to pursue constitutional changes to achieve their goals when they come to power. ${ }^{47}$ It should be noted, however, that some opinions, as far as authoritarian populism is concerned, do not attach particular importance to formal rules because they believe that these regimes use primarily informal means; and they are rather characterized by the way they manipulate, circumvent, or evade constitutional and legal rules that would limit their power. Such systems, which are sometimes referred to as competitive authoritarian regimes, often operate within the framework of seemingly democratic constitutions but neutralize control of power by informal means. ${ }^{48}$

Nevertheless, after having come to power in several countries, those generally considered 'authoritarian populists' adopted new constitutions to serve their purposes (such as in Peru in 1995, Venezuela in 1999, Ecuador in 2008, Bolivia in 2009, and Hungary in 2011), or they achieved significant constitutional reforms (such as in Turkey in 2017, or in Poland after 2015 ). As a result, it is now common to believe that it would be erroneous to underestimate the importance of formal constitutional rules in the so-called

42 Bugarič and Kuhelj (n 19) 23.

43 Andrew Arato, 'How We Got Here? Transition Failures, Their Causes and the Populist Interest in the Constitution' (2019) 45 Philosophy and Social Criticism 1108.

44 Paul Blokker, 'Populism as a Constitutional Project' (2019) 17 International Journal of Constitutional Law 552.

45 Canovan (n 18) 4.

46 David Fontana, 'Unbundling Populism' (2018) 65 UCLA Law Review 1496.

47 Blokker (n 44).

48 Steven Levitsky and Lucan A. Way, Competitive Authoritarianism: Hybrid Regimes After the Cold War (Cambridge University Press 2010) 78-81. 


\section{Zoltán Szente}

'hybrid regimes' that also include populist governments. This is shown by the success and spread of the term 'populist constitutionalism', which, however, has several rival concepts depending on how observers classify the main aspirations of these movements and their relationship to constitutional democracy.

\subsection{1 'Authoritarian', 'illiberal', or 'populist' constitutionalism?}

Although some scholars suppose that after the recent threats of constitutional democracy, which have now become a global phenomenon, no new model of constitutional systems has emerged, ${ }^{49}$ the constitutional effects of populism are considered by most academics to be so significant that it is treated as a separate category. ${ }^{50}$

The contemporary decline or backsliding of liberal democracies are defined in various ways, but many of the widely used labels such as 'constitutional breakdown', 51 'stealth authoritarianism', ${ }^{52}$ or 'democratic recession' ${ }^{53}$ indicate the process rather than the substance.

The political systems that emerge as a result of these tendencies are often referred to in political science works as 'hybrid regimes', ${ }^{54}$ or competitive ${ }^{55}$ or electoral ${ }^{56}$ authoritarianism. For many authors, some of the competing terms are interchangeable concepts or are related to each other as main and sub-groups.

Other scholars prefer to classify this legal transformation as, for example, 'autocratic legalism'57 or 'counter-constitutionalism'. ${ }^{58}$ Among the often-used terms, 'abusive constitutionalism' is frequently cited, according to which modern authoritarian regimes seek constitutional changes through which they can consolidate or preserve their power. However, a constitution or constitutional amendment for such a purpose can be considered abusive, as it is basically aimed at weakening or breaking down the limits of governmental power or making it more difficult for the opposition to come to power. ${ }^{59}$

49 Mark A. Graber, Sanford Levinson, and Mark Tushnet, 'Introduction' in Mark A. Graber, Sanford Levinson, and Mark Tushnet (eds.), Constitutional Democracy in Crisis? (Oxford University Press 2018) 3.

50 These oppositional categories, however, are not strictly correct, if we consider the question of whether or not populism has produced its own constitutional theory.

51 Wojciech Sadurski, Poland's Constitutional Breakdown (Oxford University Press 2019).

52 Ozan O. Varol, ‘Stealth Authoritarianism' (2015) 100 Iowa Law Review 1673-1742.

53 Larry Diamond, 'Facing Up to the Democratic Recession' (2015) 26 Journal of Democracy 142.

54 Matthijs Bogaards, 'How to Classify Hybrid Regimes? Defective Democracy and Electoral Authoritarianism' (2009) 16 Democratization 399-423.

55 Levitsky and Way (n 48).

56 Andreas Schedler, The Politics of Uncertainty Sustaining and Subverting Electoral Authoritarianism (Oxford University Press 2013).

57 Scheppele (n 33) 545-583.

58 Paul Blokker, 'Populist Counter-Constitutionalism, Conservatism, and Legal Fundamentalism’ (2019) 15 European Constitutional Law Review 519-543.

59 David Landau, 'Abusive Constitutionalism' (2013) 47 UC Davis Law Review 213. 
According to other approaches, populism is a political phenomenon whose constitutional ambitions are better expressed by the terms 'illiberal' or 'non-liberal constitutionalism' ${ }^{60}$ which is a stage in the process of a transition from liberal democracy to an authoritarian system, a special form of constitutional development that relativizes the rule of law, democracy, and human rights in politically sensitive matters and institutionalizes populist nationalism. ${ }^{61}$ The term can be traced back to a frequently cited article by Fareed Zakaria, ${ }^{62}$ but many politicians use the term for their own definition, ${ }^{63}$ maintaining however that their illiberal regimes - such as in Poland and Hungary - can be classified as constitutional democracies. ${ }^{64}$

The effects of populism on the constitutional system are most often referred to as 'populist constitutionalism' ${ }^{65}$ a term which is often preferred because it refers specifically to changes brought about by populist politics, while the epithets 'authoritarian' or 'illiberal' have broader meanings that can also be applied to non-populist regimes.

\subsubsection{Populist constitutionalism: an oxymoron, or a special kind of constitutional system?}

The political theory debate about the relationship between populism and democracy appears in the constitutional discourse mostly in the form of the dichotomy of populism and constitutionalism, which indicates the only existing consensus, i.e. that there is a tension between the two pillars of modern democracies, popular will and constitutionalism. ${ }^{66}$

While some scholars argue that constitutionalism also makes sense without a liberal character, ${ }^{67}$ many claim that illiberal constitutionalism is an oxymoron because constitutionalism as such can only be liberal, whereas Central and Eastern European and Latin American populist regimes are seen as authoritarian regimes. ${ }^{68}$

60 Graham Walker, 'The Idea of Non-Liberal Constitutionalism' in Ian Shapiro and Will Kymlicka (eds.), Ethnicity and Group Rights (New York University Press 1997) 169.

61 Tímea Drinóczi and Agnieszka Bień-Kacała, 'Illiberal Constitutionalism: The Case of Hungary and Poland' (2019) 20 German Law Journal 1141, 1165; Aron Buzogány, 'Illiberal Democracy in Hungary: Authoritarian Diffusion or Domestic Causation?' (2017) 24 Democratization 1307-1325.

62 Fareed Zakaria, 'The Rise of Illiberal Democracy' (1997) 76 Foreign Affairs 22-43.

63 Drinóczi and Bień-Kacała (n 61) 1148.

64 Ibid. 1149.

65 For instance, in Paul Blokker, 'Populist Constitutionalism' Verfassungsblog, 2017/5/04. https://verfassungsblog.de/populist-constitutionalism/; David Landau, 'Populist Constitutions' (2018) 85 The University of Chicago Law Review 521-543.

66 Mény and Surel (n 3) 7-11.

67 Mark Tushnet, 'The Possibility of Illiberal Constitutionalism?' (2017) 69 Florida Law Review 1367-1384; Tom Ginsburg and Aziz Z. Huq, How to Save a Constitutional Democracy (The University of Chicago Press 2018).

68 See for example Gábor Attila Tóth, 'Constitutional Markers of Authoritarianism’ (2019) 11 Hague Journal on the Rule of Law 37-61; Gábor Halmai, 'Populism, Authoritarianism and Constitutionalism' (2019) 20 German Law Journal 296-313. 


\section{Zoltán Szente}

Others suppose, however, that ' $[\mathrm{p}]$ opulist constitutionalism is, ... limited to a procedural vision of democracy', ${ }^{69}$ that is, populism does not necessarily undermine constitutional democracy, and the claim that populism is unconstitutional because of its inherent characteristics is erroneous. ${ }^{70}$ In the United States, for example, just as populism has a positive, democratic tradition, populist constitutionalism has also a progressive trend that would give the people a greater role in determining the content of the constitution, ${ }^{71}$ together with questioning or proposing at least a more moderate form of judicial review. ${ }^{72}$ Although the new wave of populism in Europe has a primarily negative reputation, it is a Janus-faced concept that has different types, and that can be authoritarian or democratic; the point is that a populist constitutionalism that combines the principles of liberal constitutionalism and democracy is possible. ${ }^{73}$ Populist constitutionalism is not a contradiction in terms if we mean by constitutionalism only that governmental practice complies with the constitutional requirements (whatever these are), and 'it is a theory of constitutions and constitutional practices that emphasizes their populist character and recommends that they develop along a populist trajectory' ${ }^{74}$

According to its characteristics, populist constitutionalism can also be understood as a coherent political theory. ${ }^{75}$ In this view, populist regimes are fighting not for an improved liberal constitutionalism, but for an alternative one based on direct legitimacy through the people. ${ }^{76}$ Just as liberal constitutionalism is in fact an aspirational idea, so illiberal constitutionalism can also be a normative concept, albeit in the opposite direction. ${ }^{77}$ Populism has a sui generis constitutionalism, a counterpart of liberal constitutionalism, and 'constitutional populism' is characteristic of government-run, institutionalized populism that pursues populist constitutional reforms, such as in Venezuela, Bolivia, or Hungary. ${ }^{78}$ Unlike anti-constitutional regimes, such systems have constitutions that limit power, but they are not centred on individual rights, and are not ideologically neutral, but are based on the

69 Fournier (n 16) 381.

70 Bugarič (n 16) 390, 395.

71 See on this, Lucia Corso, 'What Does Populism Have to Do with Constitutional Law? Discussing Populist Constitutionalism and Its Assumptions' (2014) III Rivista di filosofia del diritto, 443-470.

72 As, for example, in Mark Tushnet, Taking the Constitution Away from the Courts (Princeton University Press 1999).

73 Ibid. 391. That is, there is not only exclusionary but also inclusive populism. Cédrich M. Koch, 'Varieties of Populism and the Challenges to Global Constitutionalism: Dangers, Promises and Implications' (2020) Global Constitutionalism 9.

74 Oran Doyle, 'Populist Constitutionalism and Constituent Power' (2019) 20 German Law Journal 164.

75 Ibid. 165.

76 Landau (n 59) 541.

77 Tushnet (n 67) 1368, 1371.

78 Manuel Anselmi, Populism. An Introduction (Routledge 2018) 87. 
substantive values of ethnic, religious, or communitarian morality ${ }^{79}$ The constitutional policy of populists creates a radically different constitutional polity compared to the liberal legal-constitutional system; that is, it is a kind of response to constitutional orthodoxy,$^{80}$ even if in some countries, such as Poland or Hungary, there is a kind of counter-constitutionalism. ${ }^{81}$

However, the opposing view is that populist or illiberal constitutionalism is an oxymoron as far as authoritarian populism is concerned because liberalism is not only a restriction of the majority principle but also a precondition for democracy that guarantees the rule of law, a system of checks and balances and fundamental rights. If the main feature of constitutionalism is the legally limited power of government, then this requirement is not met, neither by authoritarian nor illiberal constitutionalism..$^{82}$ In other words, as populists reject the limits of political power, they also deny the very idea of constitutionalism, ${ }^{83}$ because constitutionalism per se means that laws must conform to liberal principles. ${ }^{84}$ As the inherent ambition of populism is to enforce the homogeneous will of a united people, it removes the limitations of the vox populi such as the separation of power, the autonomy of politically neutral bodies, or the rights of minorities. ${ }^{85}$ Thus, it does not make sense to talk about populist constitutionalism in a meaningful way, because populists undermine not only its technical and organizational characteristics, but its basic values. ${ }^{86}$ Some authors point out that this is not a static situation, but populist governance slowly, peacefully and, in a formal sense, legitimately abolishes constitutionalism, and illiberal democracy becomes an oxymoron only in the long run. ${ }^{87}$

In a sense, between these two opposing positions is the theory of 'abusive constitutionalism', which means 'the use of the mechanisms of constitutional change - constitutional amendment and constitutional replacement - to undermine democracy'. This approach sees the novelty of the contemporary global decline of liberal constitutionalism in the fact that autocrats today no longer come to power through coups and do not preserve it by open violence, but form governments through democratic elections and retain

79 Li-Ann Thio, 'Constitutionalism in Illiberal Polities' in Michael Rosenfeld and András Sajó (eds.), The Oxford Handbook of Comparative Constitutional Law (Oxford University Press 2013) 136.

80 Walker (n 35) 529.

81 Blokker (n 58) 520.

82 Halmai (n 68) 311-312.

83 Scholtes (n 17) 353.

84 Scheppele (n 33) 563.

85 Müller (n 31) 598.

86 Martin Krygier, 'The Challenge of Institutionalisation: Post-Communist "Transition", Populism, and the Rule of Law' (2019) 15 European Constitutional Law Review 570.

87 Wojciech Sadurski, 'Constitutional Crisis in Poland' in Mark A. Graber, Sanford Levinson, and Mark Tushnet (eds.), Constitutional Democracy in Crisis? (Oxford University Press 2018) 272; Gábor Attila Tóth, 'Breaking the Equilibrium: From Distrust of Representative Government to an Authoritarian Executive' (2019) 28 Washington International Law Journal 321. 


\section{6}

\section{Zoltán Szente}

their power by constitutional means. Such constitutional systems seem distantly democratic and contain many elements that can also be found in liberal constitutions; in reality, however, on closer inspection, they undermine democracy, as in Colombia, Venezuela, and Hungary. 'They are increasingly turning towards constitutional amendment and replacement as tools to help them construct a more authoritarian order', and use 'mechanisms of constitutional change in order to make a state significantly less democratic than it was before' ${ }^{88}$

The background of these conceptualization debates is that while some accept the formal(ist) notion of constitutionalism, according to which it means the mere existence and enforcement of a constitution regardless of its content, others view constitutionalism in a 'material' sense; that is, according to them, it is possible to talk about constitutionalism in a meaningful way, only if certain (liberal) constitutional principles prevail in practice.

It is also worth noting that some authors distinguish between different forms of populist constitutionalism within its conceptual scope, making a distinction between, for example, 'inclusive' and 'exclusionary', ${ }^{89}$ 'cosmopolitan' and 'communitarian' ${ }^{90}$ constitutionalism (which are, in fact, repercussions of the liberal-illiberal dichotomy in other contexts), national and transnational constitutional populism, ${ }^{91}$ and so on.

\subsubsection{Defining populist constitutionalism: positive and negative criteria}

Despite these conceptual debates, there is a broad consensus that populism has now posed a significant challenge to the institutions and principles of constitutional democracies, and that the category of populist constitutionalism has become so widespread that its use or exploration, even in a critical sense, can hardly be ignored if we want to understand this challenge.

Populist constitutionalism is often defined not only as the antithesis of liberal constitutionalism, but also on the basis of one or more of its characteristics. Many authors highlight a single aspect as a defining feature. Of course, these criteria are very often the same as the different conceptualizations of populism, or their constitutional transformations. Thus, for example, according to one conceptual attempt, populist constitutionalism is a constitutional practice based on the conflict between two homogeneous and antagonistic groups (a homogeneous people on the one side, and special interest groups such as the power establishment, technocrats, international organizations, immigrants, certain minority groups on the other) which redefines the balance between individual and collective interests. ${ }^{92}$ Others suppose it to be a

88 Landau (n 59) 191, 195.

89 Blokker (n 25) 343.

90 Koch (n 73) 3.

91 Blokker (n 25) 344.

92 Walker (n 35) 516, 533. 
constitutional strategy aimed at consolidating power, ${ }^{93}$ while some identify this concept with the specific perception of the nature of constituent power and popular sovereignty. ${ }^{94}$

Some conceptual criteria that can be identified from the literature are negative ones, in the sense that populism and populist constitutionalism are often defined as criticisms or denials of certain key features of traditional constitutional democracies. At the same time, there are also positive criteria that relate to the main values, principles, and institutional solutions of this type of constitutionalism.

Most of these criteria, as we shall see, are characteristic of authoritarian populism and its constitutional conception; this is hardly surprising, since in practice this is the prevailing trend today. It is also important to note that the following characteristics are not specific to all populist governments or movements but are present in various countries to different degrees and in different combinations, and in the end, the various traits cannot be sharply separated from each other, i.e. there may be significant overlaps between them.

\subsubsection{Negative criteria of populist constitutionalism}

\subsection{CRITICISM OF THE SEPARATION OF LAW AND POLITICS}

Populists are usually critical of the liberal conception of constitutionalism and the rule of law, criticizing its depoliticization because it removes people from institutions. According to Paul Blokker, there is no difference between right-wing and left-wing populism in that both oppose the separation of law and politics, which means that populism rejects the restriction of political power by legal norms. ${ }^{95}$

Some scholars apply the theory of political constitutionalism to populist constitutional policy, claiming that the constitutional ambitions of populism represent a shift from legal to political constitutionalism; that is, they aim to establish a new constitutional order that supports the will of the people and the common good against particular interests. ${ }^{96}$ However, this interpretation has also provoked controversy in the literature, as some authors argue that populist or illiberal constitutional aspirations, insofar as they seek to dismantle checks and balances, do not meet the democratic requirements of political

93 Simone Chambers, 'Democracy and Constitutional Reform: Deliberative versus Populist Constitutionalism' (2019) 45 Philosophy and Social Criticism 118.

94 Luigi Corrias, 'Populism in a Constitutional Key: Constituent Power, Popular Sovereignty and Constitutional Identity' (2016) 12 European Constitutional Law Review 9; Doyle (n 74) 164.

95 Blokker (n 44) 535-537, 539.

96 Lech Morawski, 'A Critical Response' Verfassungsblog, June 3, 2017.; Blokker (n 58) 531-532, Blokker (n 44) 539. 
constitutionalism, as the latter does not mean unlimited public power, but this theory stresses that the restriction of power is of a political nature. ${ }^{97}$

Some argue that populists' 'legal resentment' is motivated by the fact that the politically neutral conception of law in a liberal democracy undermines the representation of the national interest because, for example, it allows constitutional courts and other supreme courts to obstruct the popular will. ${ }^{98}$

\subsection{ANTI-ELITISM}

It is a common feature of the various approaches of populism that one, if not the most essential, characteristic of this political phenomenon is the juxtaposition of the virtuous people and the corrupt elite, and their opposition to the elite's interests. In addition, populists refer to a united people (nation, community), or 'ordinary' people as opposed to a privileged cosmopolitan elite, i.e. to average people whose interests are suppressed by an arrogant elite, corrupt politicians, or minorities. ${ }^{99}$ 'Populists are anti-establishment politicians - figures who, claiming to represent the voice of "the people", wage war on what they depict as a corrupt and conspiratorial elite'. ${ }^{100}$ Notably, it is a radical anti-elitism that recognizes the will of the people as the only source of constitutional legitimacy. ${ }^{101}$ Populism differs from other anti-regime groupings in that it questions not only those in power but also the values of the elite. ${ }^{102}$ Not only does it sharply criticize the power elite, but in its political program, it also promises that by coming to power, people will take back control or take their country back from elites who usurp power. ${ }^{103}$

Nevertheless, there is some variety as to what groups are designated as part of the elite. Most often, politicians and parties in power (if they are not the populists themselves) are classified in this circle, but officials of the most anti-majoritarian institutions, such as the judges of the constitutional courts or ordinary courts, are frequently seen as elitist groups against whom the real will of the people must be enforced. But international organizations or EU institutions are also often seen as obstacles to popular will.

97 Pablo Castillo-Ortiz, 'The Illiberal Abuse of Constitutional Courts in Europe' (2019) 15 European Constitutional Law Review 63, 65; Halmai (n 68) 302, 304; Drinóczi and Bień-Kacała (n 61) 1161-1162.

98 Blokker (n 44) 549, 551.

99 Canovan (n 18) 5.

100 Steven Levitsky and Daniel Ziblatt, How Democracies Die (Crown Publishing 2018) 22.

101 Valerio Fabbrizi, 'Constitutional Democracy in the Age of Populisms: A Commentary to Mark Tushnet's Populist Constitutional Law' (2019) Res Publica, https://doi. org/10.1007/s11158-019-09430-7; Bojan Bugarič, 'Central Europe's Descent into Autocracy: A Constitutional Analysis of Authoritarian Populism' (2019) 17 International Journal of Constitutional Law 598; B. Guy Peters and Jon Pierre, 'A Typology of Populism: Understanding the Different Forms of Populism and Their Implications' (2020) Democratization, DOI: 10.1080/13510347.2020.1751615; Mudde (n 8) 543, 546; Müller (n 10) 2; Müller (n 31) 593.

102 Canovan (n 18) 3.

103 Mueller (n 16) 1026. 
It is to be noted, however, that anti-elitism is often merely rhetoric, used mostly by populist opposition movements and politicians, and not infrequently selective - at least as is shown by the fact that some politicians generally classified as populists themselves belonged to the political (like the Hungarian Viktor Orbán or the Polish Jarosław Kaczyński) or the economic elite (like Silvio Berlusconi in Italy or Donald Trump in the United States) when they came to power. On the other hand, experience shows that populist governments are not inherently or generally anti-elitists, as they themselves often pursue elitist policies once they come to power, i.e., their political program is indeed more about only replacing the ruling or former elite.

The 'people', which is postulated as a uniform one, is often opposed by populist politicians not only to the ruling elite, but also to certain minority groups, such as LGBTQ communities or immigrants, whose distinctive features differ from the morality or identity of the majority. Populist governments can discriminate against enemy groups by legal means, also stigmatizing NGOs and alternative churches, or restricting their operations.

\subsection{ANTI-INSTITUTIONALISM}

Populism is usually characterized not only by its radical anti-elitism but also by its distrust of traditional institutions. This is often explained by the fact that populists see these institutions as obstacles to the will of the people, and when they come to power they weaken or dismantle them if they obstruct populist governance. ${ }^{104}$ The illiberal version of populism rejects the constitutional limits of state power and the protection of minority rights. ${ }^{105}$ Because non-majoritarian public bodies are generally seen as unnecessary intermediaries between the government and the people, anti-institutionalism can be characteristic even of populist movements that are considered democratic.

As we have pointed out, this kind of mistrust tends to manifest itself primarily against non-elected or anti-majoritarian institutions, in particular the constitutional courts, supreme and ordinary courts, and other politically neutral bodies such as election commissions or ombudsmen. Political attacks and structural changes can also target different types of supervisory bodies (such as media authorities, or economic competition authorities). This can take place in a number of ways, from political pressure to packing the institutions with loyal people, but here formal legal changes have special significance.

Constitutional changes offer an effective framework for these efforts, and populist governments in several countries have attempted to pass a new constitution or substantially amend the existing basic law. In Venezuela, for example, President Hugo Chávez convened a Constituent Assembly in 1999 to draft a new constitution, which was confirmed in a referendum in the 
same year, and in 2009 another referendum abolished the constitutional limitation on presidential re-election. The same took place in Ecuador after the election of President Rafael Correa in 2007. In Hungary, the MPs of the ruling party coalition, which won a constitution-making majority in the 2010 general elections, voted for a new constitution in 2011 , which has since been adapted nine times in favour of the current political interests of the governing parties. Russia and Turkey accomplished several constitutional reforms in the 2000s that strengthened presidential power, while in Poland, without formal constitutional amendments, significant structural changes were made, including through parliamentary legislation which put the Constitutional Court and the Judiciary under political control.

The lack of confidence in the existing institutional system naturally stems from a populist political view that identifies public bodies with a corrupt elite, ${ }^{106}$ but perhaps more weight is given to power interests, that is, to neutralizing independent countervailing bodies and dismantling the system of checks and balances.

As a matter of fact, what we have seen with anti-elitism also applies in this respect: populists are not generally anti-institutional, for when they come to power, they try to put public authorities at the service of their own ends. ${ }^{107}$ As Levitsky and Ziblatt claim, for autocrats, independent institutions are both a threat and an opportunity, so they are transformed so as to serve as an effective means of selectively enforcing laws, punishing opponents, and protecting their own people. ${ }^{108}$ Institutional changes are therefore devoted to strengthening the executive and occupying and weakening countervailing powers. ${ }^{109}$

Overall, populist constitutions do not abolish the institutions of liberal democracy but merely imitate their operation, as they do not work in accordance with their original function but serve the interests of the authoritarian government. ${ }^{110}$

\subsection{ANTI-PLURALISM}

There is also a broad consensus among scholars that populists are against pluralism, considering themselves the only genuine representatives of the real interests of the people. ${ }^{111}$ Most populist parties are critical of the functioning of representative democracy and often question the legitimacy and role of traditional parties. ${ }^{12}$ This is because, according to the populist political view,

106 Landau (n 59) 526.

107 Müller (n 31) 598; Müller (n 10) 39; Landau (n 59) 537-539.

108 Levitsky and Ziblatt (n 100) 78.

109 Chris Thornhill, 'Constitutionalism and Populism: National Political Integration and Global Legal Integration' (2020) 12 International Theory 2.

110 Tóth (n 68) 52-53.

111 Mudde (n 8) 543; Müller (n 31) 593; Müller (n 10) 3; Bugarič and Kuhelj (n 19) 26.

112 Blombäck (n 13) 221; Urbinati (n 14) 113. 
the people are united and indivisible, with a clear and recognizable will, and pluralism is a threat in their eyes to the real public interest. ${ }^{113}$

Anti-pluralism can be mere rhetoric, or in the constitutional sense it can mostly mean the restriction of freedom of expression and other political rights, the biased transformation of the electoral system, the obstruction of the operation of opposition parties, and so on.

\subsection{ILLIBERALISM}

As has been said, the emergence of populist movements is often seen as a challenge to liberal democracy, and their aspirations or views on the constitution are frequently referred to by many as illiberal constitutionalism. This is emphasized by many authors because this category is sufficiently broad to include politicians and parties that are not anti-democratic ${ }^{114}$ within a populist conception. Certainly, this definition is not acceptable for those who identify democracy with its liberal form, supposing that populist constitutionalism rejects, or at least limits, the system of checks and balances, judicial review of laws, and in general any players with a veto which restricts the real will of the people, ${ }^{115}$ because these guarantees are considered by many to be essential requirements and accessories of modern democracies.

However, the populist form of constitutionalism can be considered anti-liberal not only because of the rejection of power-sharing, but also because of the limitation of the protection of minorities and individual rights, which follows from the foundations of communitarian populism, according to which the public interest and the general will of the people should take precedence over individual and particular interests.

Both the dismantling of institutional barriers and the erosion of the rule of law, as well as the restriction of the protection of minorities and individual rights require constitutional-legal changes, as exemplified by populist constitutions and recent constitutional developments in countries with populist governments. Although there have been few or no examples of such institutional changes in several Central and Eastern European post-Soviet states, Poland's and Hungary's performance have deteriorated significantly in various independent surveys, rule of law and corruption indices, and reports of international human rights organizations since they have been ruled by populists, while Russia, Turkey, and Venezuela have generally been classified as consolidated autocracies.

\subsubsection{Positive criteria of populist constitutionalism}

Nevertheless, there are not only negative indicators among the criteria of populist constitutionalism, denying or criticizing certain constitutional 


\section{Zoltán Szente}

principles and institutions, but also positive criteria that offer a kind of answer or solution to the perceived or real democratic deficit of liberal constitutionalism. Some say, for example, that in Poland and Hungary, conservative populists want to build an alternative, 'counter-constitutional' order to replace liberal constitutionalism. ${ }^{116}$

Among these positive characteristics, those on which there is a broad consensus can be considered 'primary' criteria, while others are 'secondary' features that are attributed to populist constitutionalism by some academics but do not have a general recognition in scholarship. Many of these criteria are also closely related to and overlap each other, but it is worth separating them for analysis and clarity.

\subsection{POPULAR SOVEREIGNTY AND DIRECT DEMOCRACY}

Populist constitutionalism arises with the claim to directly represent the 'average people', that is, to enforce popular sovereignty. ${ }^{117}$ As the public interest is uniform and can precisely be defined, ${ }^{118}$ the function of representation is to implement it consistently and without hindrance. ${ }^{119}$ This is based on a conception of popular sovereignty that sees the majority formed in elections as the sole source of democratic legitimacy. ${ }^{120}$

Consequently, the people are the constituent power, not in the institutionalized, indirect form as in liberal democracies, but as an imaginary entity whose will is not limited by the existing constitutional order. In other words, a populist interpretation of constituent power puts the rule of the people above the rule of law, ${ }^{121}$ whatever that means.

Several authors point out that populists do not mean people in the empirical sense, that is, the community of citizens, but that there is no longer any consensus on what the constructivist conception of the people exactly signifies. Some say populism identifies the people with the majority of the electorate, ${ }^{122}$ but they can think of the sovereign in the abstract sense, the 'ordinary people' or the nation ${ }^{123}$ (ethnic community), while the concept of people often appears as a sort of mystical, homogeneous, and moral entity, ${ }^{124} \mathrm{a}$ 'collective subject' stuck together by tradition, common suffering, and destiny. ${ }^{125}$

116 Blokker (n 44) 542.

117 Ibid. 536-537.

118 Müller (n 10) 26; Corrias (n 94) 11.

119 Scholtes (n 17) 354.

120 Mueller (n 16) 1033.

121 Corrias (n 94) 9.

122 Mueller (n 16) 1036).

123 Mudde and Kaltwasser (n 15) 9.

124 Mudde (n 8) 546; Müller (n 10) 28.

125 Blokker (n 44) 542 . 
Yet, references to 'people' may lead to different value choices, depending on whether they are referred to in terms of plebs, demos, or ethnos. ${ }^{126}$

Some authors argue, however, that this reference to the people in terms of an abstract and unified entity is merely rhetoric, and populism is in fact a plebiscite conception of democracy in which the expression of the will of the electorate is limited to participation in elections. ${ }^{127}$ Populists more often than not consider the people to be a passive mass, and once the representation of the genuine will of the people has taken place, there is no need for further popular participation. ${ }^{128}$ In contrast, many authors argue that populism is characterized by a preference for direct democracy over institutionalized representation. ${ }^{129}$

In practice, the picture is very controversial. For example, while the Brexit referendum, generally held to be a populist enterprise, brought about significant political and constitutional changes in the United Kingdom, which is traditionally averse to direct democracy, unrestricted populist governance in Hungary confined the institution of referendum to serve governmental interests. $^{130}$

\subsection{AUTHENTIC POPULAR REPRESENTATION}

According to a significant part of the literature on populism, this political ideology, style, or rhetoric is characterized by the claim to be an authentic and exclusive representation of the people imagined in the aforementioned sense. ${ }^{131}$ Populist parties differentiate themselves from other parties by claiming that they represent the real interests of the people instead of the elite, ${ }^{132}$ and they build their legitimacy on this base. ${ }^{133}$ It is clear that the claim to authentically represent the people is a logical consequence of the aforementioned anti-pluralism, and that populists have as little trouble with

126 Rogers Brubaker, 'Why Populism?' in Gregor Fitzi, Jürgen Mackert, and Bryan S. Turner (eds.), Populism and the Crisis of Democracy. Volume 1: Concepts and Theory (Routledge 2018) 28.

127 Thornhill (n 109) 3.

128 Müller (n 31) 594.

129 Bugarič (n 16) 392; Bojan Bugarič, 'Central Europe's Descent into Autocracy: A Constitutional Analysis of Authoritarian Populism' (2019) 17 International Journal of Constitutional Law 598, Fabbrizi (n 101), Chambers (n 93) 117, Corrias (n 94) 12, 19.

130 Since 2010, hundreds of referendum initiatives have been rejected by the Fidesz-controlled National Electoral Commission, and only one national referendum, initiated by the government in an obviously unconstitutional manner, has taken place. See for this Zoltán Szente, 'The Controversial Anti-Migrant Referendum in Hungary Is Invalid' https://constitutional-change.com/the-controversial-anti-migrant-referendum-in-hungary-is-invalid/.

131 Müller (n 31) 593; Gábor Halmai, 'A Coup Against Constitutional Democracy. The Case of Hungary' in Mark A. Graber, Sanford Levinson, and Mark Tushnet (eds.), Constitutional Democracy in Crisis? (Oxford University Press 2018) 253.

132 Corrias (n 94) 11.

133 Canovan (n 18) 4. 


\section{Zoltán Szente}

representation if they are the representatives, just as political-administrative elitism is not the devil's work if they themselves make up the elite. ${ }^{134}$ The almost natural consequence of this is the de-legitimization of the opposition, the limitation of its resources, and the disregarding of its proposals and initiatives, and the elimination of political discourse with the opposition parties.

Although the claim to be the authentic representatives of the people is often only part of the communication of populist politicians and movements, ample evidence indicates that in practice, populist governments, when they have the opportunity, seek to consolidate their power using constitutional or legal means. There are several ways to do this. Whereas government control of the media, widespread patronage, smear campaigns against the opposition, and their delegitimization are basically elements of the political toolbox, ${ }^{135}$ such efforts can be effectively facilitated by various legal techniques. For example, biased intervention in the electoral system to provide illegitimate advantage for the governing parties over the opposition can most effectively be achieved through constitutional and legal reforms.

In the populist mindset, the authentic representation of the people also legitimizes the desire to see the one-time election victory - that is, the populist parliamentary majority - as a permanent but at least long-lasting mandate, so that later general elections become mere electoral approval of government policy. ${ }^{136}$

\subsection{EXTREME MAJORITARIANISM}

Populist constitutionalism can be characterized by the absolutization of the majority principle as long as the 'right' parties have won the election. ${ }^{137}$ This majoritarian conception of democracy regards electoral empowerment as an expression of the will of the people and, on that basis, rejects the constitutional restriction of power. ${ }^{138}$ This vision looks at politics as a zero-based struggle for dominance between political adversaries, claiming that only parties or politicians that have won a majority in elections can legitimately participate in political decision-making. ${ }^{139}$ This idea may justify weakening non-elected controlling institutions, rejecting any veto of majority decisions based on legal or constitutional considerations, and ultimately contrasting the majority principle with the rule of law. ${ }^{140}$ Here again, the repudiation of

134 Müller (n 10) 30.

135 Landau (n 59) 199; Mueller (n 16) 1037, 1041.

136 Müller (n 10) 63; Mueller (n 16) 1041.

137 Blokker (n 44) 543.

138 Landau (n 59) 533; Mudde (n 8) 561; Mueller (n 16) 1035; Scheppele (n 33) 562; Urbinati (n 14) 113.

139 Mueller (n 16) 1036.

140 Fournier (n 16) 366. 
pluralism can be observed, as it considers the actual governing majority as a permanent one rather than a result or outcome of the continuous political struggle between rival parties, and it is reluctant to recognize minority interests' need for protection against the will of the majority. ${ }^{141}$

In reality, this does not mean a total denial of the protection of minorities or individual rights, but it does mean that these rights, depending on the weight of the presumed or real community interests, can be restricted to a much greater extent than in the practice of consolidated constitutional democracies.

\subsection{THE STRONG LEADER (PERSONIFICATION OF POWER) AND THE STRENGTHENING OF EXECUTIVE POWER}

Another widely recognized feature of populist constitutionalism is the concentration of power in the hands of a charismatic, strong leader. ${ }^{142}$ Populists such as the American Donald Trump, the Russian Vladimir Putin, Recep Tayyip Erdoğan in Turkey, the Venezuelan President Nicolás Maduro, the Hungarian Prime Minister Viktor Orbán, and even the Polish Jarosław Kaczyński, who is without any leading position in government, and the French and Dutch opposition party leaders Marine Le Pen and Geert Wilders are all allegedly claiming that they are the genuine leaders of their people against corrupt elites. ${ }^{143}$

One of the characteristics of populist political leaders is that they differentiate themselves from the traditional elite by not following conventional forms of political behaviour in their politics or communication style, ${ }^{144}$ by blending visions, and by flexibly alternating their statements and opinions. They also need to do so because, in fact, they often belonged to the former elite themselves, sometimes for decades, ${ }^{145}$ such as the aforementioned politicians Orbán or Wilders; or Trump or Berlusconi, who belonged to the economic elite before starting their political careers.

Constitutional law can also be an effective tool for centralizing power, either by strengthening the executive (see, for example, the institutionalization of Latin American 'super-presidential' systems or the Turkish presidential system) or by neutralizing counterbalancing institutions or removing re-election barriers (as occurred in several South American countries or in Russia with the 2020 constitutional amendment).

141 Fontana (n 46) 365.

142 Bugarič and Kuhelj (n 19) 27; Drinóczi and Bień-Kacała (n 61) 1159; Landau (59) 539; Müller (n 10) 33; Pappas (n 29) 71-72. However, some do not consider this, together with some other criteria, to be a criterion for populism. See Kaltwasser (n 6) 68.

143 Bugarič (n 129) 598.

144 Blombäck (n 13) 220.

145 Fontana (n 46) 1502; Müller (n 10) 34; Mudde (n 8) 560; Peters and Pierre (n 9l) 5. 


\section{Zoltán Szente}

\subsection{THE INSTRUMENTALIZATION OF LAW}

As has been said earlier, one of the peculiarities of contemporary populism is the recognition that the constitution can provide an effective toolbox for preserving power and breaking down checks and balances, so populist regimes are characterized by active constitution-making, as far as this is possible for them.

Nevertheless, the perception of law as an instrument of power itself is not one of the openly acknowledged values of populist political ideology, although in practice, this approach makes it easier to realize these values. Consequently, we can identify it as a common feature of populist constitutionalism. This way of thinking regards law on the one hand as a means of realizing political will, and on the other hand as a necessary condition for the preservation of power. ${ }^{146}$ Besides this, in authoritarian populist systems, the formal legitimization of political decisions and the maintenance of the appearance of democracy and rule of law are important functions of the legal system. ${ }^{147}$

Constitutional changes provide particularly effective opportunities for all this, provided that the populists are able to enforce their perception of the role and normative nature of the constitution. This is because constitutional changes override all previous rules and can have a lasting effect. At the same time, in a case in which the aim of the constitution-making is to radically change the political system and to consolidate governmental power, the function of the basic law will change significantly: it will be no longer a guarantee of the status quo, but an engine of transformation. This necessarily conflicts with the normative and permanent nature of the constitution, not only where populists have the opportunity to amend the constitutional text as they wish (such as in Hungary, Russia, or Turkey), but also where - in the absence of a constitution-making majority - they achieve the same effect through the reinterpretation of the constitution (as in Poland).

Some scholars point out that the legalization of political decisions, regardless of their content, merely formally upholds constitutionalism; that is, it actually only imitates legality. ${ }^{148}$ For this purpose, populists actually adopt 'pseudo-' or 'façade constitutions'149 which, instead of restricting power, help to secure and perpetuate the power of populists, and with which autocrats disguise the true character of the system. And while many researchers on populism note that populist regimes carefully maintain formal legalism, in reality they very often circumvent or simply ignore their own constitution. ${ }^{150}$

146 Blokker (n 44) 545; Landau (n 59) 532; Müller (n 10) 63; Müller (n 31) 598.

147 Tóth (n 68) 52.

148 Levitsky and Ziblatt (n 100) 77; Scheppele (n 33) 573.

149 See Giovanni Sartori, 'Constitutionalism: A Preliminary Discussion' (1962) 56 American Political Science Review 853, 861; David S. Law and Mila Versteeg, 'Sham Constitutions' (2013) 101 California Law Review 863-952; and Tóth (n 68) 51.

150 Walker (n 35) 520. 
These 'secondary' criteria are often specific to certain regions or countries, or only to populist politics associated with specific ideologies, or deserve to be mentioned precisely because of their constitutional significance.

One of these characteristics is the preference for the concept of constitutional identity. Some argue that populists aim to define and defend the identity of the community, ${ }^{151}$ or to set in stone their own image of the peo$\mathrm{ple}^{152}$ through constitutional changes. Moreover, constitutionalization can be a means of giving the nation a nationalist and religious concept and thus supporting authoritarian intentions. ${ }^{153}$ The background motivation can be to symbolically strengthen the political unity of the people (or the supporters) and, through this, to legitimize populist governance, ${ }^{154}$ despite the fact that, according to experience, the values included in the constitutions do not usually contain the real popular values. ${ }^{155}$

The legitimacy of populist rule is also supported by the abusive legal borrowing of certain legal institutions or procedures; more precisely, the way of argumentation which justifies some controversial constitutional-legal solutions by the fact that they also occur in consolidated democracies. These regimes frequently refer to the institutional patterns of developed Western democracies ${ }^{156}$ and object to the 'double standard' that is used by those who criticize the populist institutional and legal reforms. Indeed, there are examples of almost all of the institutional settings brought about by populist regimes in consolidated democracies, but they meet the requirements of the rule of law individually and not as a whole. ${ }^{157}$ The use of foreign patterns taken out of their context leads to a 'Frankenstein state' that 'is composed of various perfectly reasonable pieces, and [whose] monstrous quality comes from the horrible way that those pieces interact when stitched together' ${ }^{158}$

Some scholars also specify crisis management as a source of legitimacy for populism because an external threat gives populists the opportunity to legally break free from the limits of power. ${ }^{159}$ In Turkey, for example, the failed coup in 2016 provided an opportunity for the government to impose repressive measures, followed by the introduction of a presidential system in 2017 with a referendum strengthening President Recep Tayyip Erdoğan's power, while

151 Blokker (58).

152 Müller (n 31) 603; Corrias (n 94) 23.

153 Halmai (n 68) 310; Cesare Pinelli, 'The Rise of Populism and the Malaise of Democracy' in Sacha Garben, Inge Govaere, Paul Nemitz (eds.), Critical Reflections on Constitutional Democracy in the European Union (Hart 2019) 42.

154 Thornhill (n 109) 2; Walker (n 35) 522.

155 Mila Versteeg, 'Unpopular Constitutionalism' (2014) 89 Indiana Law Journal 1137.

156 Rosalind Dixon and David Landau, '1989-2019: From Democratic to Abusive Constitutional Borrowing' (2019) 17 International Journal of Constitutional Law 493.

157 Mark Tushnet, 'Varieties of Populism' (2019) 20 German Law Journal 386.

158 Kim Lane Scheppele, 'The Rule of Law and the Frankenstate: Why Governance Checklists Do Not Work' (2016) 26 Governance 560.

159 Levitsky and Ziblatt (n 100) 93. 
in Hungary the outbreak of the coronavirus pandemic in 2020 led to the declaration of an emergency situation providing an unlimited authorization for the Orbán government, the most important elements of which were later enacted, i.e. perpetuated, by the two-thirds parliamentary majority of Fidesz after the end of the special legal order. Some authors presume that populists sometimes invent or exacerbate a crisis situation themselves because citizens are more tolerant or even supportive of authoritarian measures in times of crisis that threaten their security. ${ }^{160}$ Populism usually does not emerge in stable, orderly conditions, which is also the reason why populist governance is said to be difficult to maintain in the long run, or after normalcy returns. ${ }^{161}$

Among the operational characteristics of populist, illiberal states, the restriction of certain fundamental rights, as well as the intolerance of or discrimination against certain minorities, can be highlighted. This usually affects political rights, especially freedom of expression, academic freedom, and the right of assembly and association. Presumably, the more authoritarian a populist system becomes, the more likely it is that personal freedom will be restricted. ${ }^{162}$ Negative campaigning, and direct and indirect discrimination against Roma, immigrants, LGBTQ communities or certain religious 'sects' that do not belong to the people or endanger their culture and identity, are also frequent phenomena. These actions may not only be taken through political or administrative measures, but they may also gain a legal-constitutional basis through legal preference, for example, for the traditional family model, the discriminatory regulation of the status of churches and NGOs, or the tightening of certain fundamental rights restrictions.

These manifestations of 'nativism' are often associated with anti-globalism, insofar as populism is hostile to all 'foreign' political values because it sees them as a threat to national sovereignty or to the true will of the people. In populist rhetoric, this threat is most often represented in Europe by the EU institutions and the European courts, but the alleged evidence of the threat can be, for example, EU immigration policy or criticisms from international organizations (interpreted as attacks on 'Hungarians', 'Poles', or 'Turks'). It is important to add, however, that some views also see progressive political tendencies (such as the Greek Syriza Party) which are not characterized by anti-liberalism and nativism, as populist. ${ }^{163}$

Clientelism, state capture, and the 'Gleichschaltung' of certain social systems (putting them under direct political control), which are also characteristic of populist governments, require the use of legal instruments as well.

160 Levitsky and Ziblatt (n 100) 94, 208; Müller (n 10) 43; Blombäck (n 13) 223.

161 Paul Taggart, 'Populism and the Pathology of Representative Politics' in Yves Mény and Yves Surel (eds.), Democracies and the Populist Challenge (Palgrave MacMillan 2002) 69.

162 See e.g. Sadurski (n 51); Sadurski (n 87) 268-270; Tóth (n 68) 54; Bugarič (n 129) 607-608.

163 Robert Howse, 'In Defense of Disruptive Democracy - A Critique of Anti-Populism' (2019) 17 International Journal of Constitutional Law 643. Howse defines populism as any action against the elitist policies of advanced liberal democracies. Ibid. 641. 
According to some authors, the systematic patronage, clientelism, ${ }^{164}$ and the 'colonization' of the state - that is, the 'occupation' of the most important institutions (filling them with politically loyal people) - are features of populism. ${ }^{165}$ In a sense it is not surprising, because if populists consider themselves to be the only true representatives of the people, it is justified to take possession of public institutions and to take action against those who obstruct the pursuit of the genuine public interest. ${ }^{166}$ It is to be noted, furthermore, that the power ambitions of populists are not limited to political institutions, but are also aimed at influencing certain social sub-systems, as a consequence of their identity-based ideology. This can be manifested by stigmatizing the politically suspicious non-governmental organizations, restricting their operation, interfering in the scientific and artistic sphere and in the system of public education, for which legislation provides opportunities, as is also the case in the often statist, protectionist economic policy.

Whatever combination of the aforementioned primary and secondary criteria of populist constitutionalism is achieved in a country, it is sure that they raise a significant challenge to traditional representative government and liberal constitutionalism. And if they have, or may have, such an important effect on the functioning constitutional systems, then it can be rightly assumed that this influence extends to the methods of constitutional interpretation and, of course, to its outcome. However, in order to assess this effect, it is necessary to clarify the nature and definition of the constitutional interpretation which is as controversial as the concepts of populism and populist constitutionalism themselves. It is discussed in the next chapter.

164 Müller (n 31) 597; Pappas (n 29) 72, 74.

165 Pappas (n 29) 73; Landau (n 59) 200.

166 Müller (n 31) 596. 